der Wirkung ionisierender Strahlen auf das Blut von Amphibien beschränken sich auf wenige Arbeiten [5, 6] und sind durch eine unzureichende Darstellung der Methodik schwer zu bewerten. Umfassendere Daten gibt es über die Radiosensitivität von Embryonen sowie über die Ermittlung von Schwellenwerten $[7,8]$.

Alle diese Arbeiten waren jedoch für die phylogenetische Gegenüberstellung niederes-höheres Wirbeltier konzipiert. Bei der ständig wachsenden Belastung unserer Gewässer kann die bloße Erfassung der Schwellenwerte und der letalen Dosen jedoch nicht ausreichen. Es sollte Organismen und methodische Möglichkeiten geben, die schwache Belastungen anzeigen können, um rechtzeitig vorbeugende Maßnahmen einleiten oder im nachhinein die Art der Kontamination und den Einleitungsort zurückverfolgen zu können.

Angeregt durch mehrere Arbeiten [9-12] nutzten wir die Veränderungen im Serumproteinprofil als Zeigerparameter. Der Einfluß ionisierender Strahlen wurde bisher fast ausschließlich an Säugern nach Bestrahlung untersucht: Panke [9] beschreibt nach einer Einmalbestrahlung bei Hunden einen signifikanten Anstieg der $\alpha_{2^{-}}$ Bande auf Kosten der Albumin-Fraktion. Auch Simsa [10] verwies auf einen starken Anstieg einiger SerumproteinFraktionen, die aber, soweit die Tiere dann nicht bereits irreversibel beeinträchtigt waren, spätestens nach drei Wochen wieder das Kontrollniveau erreicht hatten. Chlebovska et al. [11] untersuchten die quantitativen Veränderungen der Serumproteine nach Bestrahlung bei Ratten. Diese Verände- rungen wurden mit den Überlebensraten korreliert, können also keine Indikatorfunktion erfüllen. Malhotra [12] beschreibt die Wirkung einer Ganzkörperbestrahlung mit 3 Gy auf die Serumproteine weißer Mäuse. Während Albumin, $\beta$-Globulin und $\gamma$-Globulin eine nicht-signifikante Erhöhung zeigen, läßt das $\alpha$-Globulin-Niveau eine Abnahme erkennen. Auch diese Proteinverschiebungen waren - sofern die Bestrahlung nicht zum Tod der Versuchstiere führte - reversibel. Esber et al. [13] berichteten, daß bei bestrahlten Hunden alle Serumproteine außer der $\alpha_{2}$-Globulin-Fraktion, die um $50 \%$ anstieg, reduziert waren. Die Autoren erklären die Zunahme der $\alpha_{2}$-GlobulinFraktion mit beginnenden Entzündungsprozessen, die Abnahme der übrigen Serumproteine mit strahlenbedingter Lymphknoten- und Leberzerstörung. Beide Vermutungen können durch eigene Untersuchungen insofern nicht bestätigt werden, als die $\alpha_{2}$-GlobulinZunahme nicht nur irreversibel ist, sondern auch auf die Filial-Generation vererbt wird.

Die von uns am Wirbeltier erarbeiteten Daten legen erstmalig und eindeutig dar, daß ein definiertes Serumprotein, die $\alpha_{2}$-Globulin-Fraktion, die mit mehreren elektrophoretischen Verfahren dargestellt werden konnte, durch völlig verschiedenartige Strahlenbelastungen irreversibel signifikant verändert wurde. Diese Dysproteinämie tritt auch im Serum der Nachkommen strahlenbelasteter Elterntiere auf. Die Reproduzierbarkeit verleiht diesen Serumproteinverschiebungen ein Zeigerpotential in einem amphibisch lebenden Wirbeltier von hohem Stellenwert.
Der Indikatororganismus kann sowohl akut zur Kontaminations-Prävention und Beweisführung nach Unfällen als auch chronisch im Rahmen fortlaufender Emmissions-Checks eingesetzt werden.

Diese Untersuchung ist Teil eines vom Bundesministerium für Umwelt, Naturschutz und Reaktorsicherheit geförderten Forschungsvorhabens.

Eingegangen am 30. November 1989 und 19. Januar 1990

1. Kloft, W. J., Gruschwitz, M.: Ökologie der Tiere. Stuttgart: Ulmer 1987

2. Strick, H., Giannetti, M., Kloft, W. J.: Z. Angew. Zool. (im Druck)

3. Strick, H., Giannetti, M., Pantel, K., Kloft, W. J.: ibid (im Druck)

4. Heineke, H.: Mitt. Grenzgeb. med. Chir. 14, 21 (1904)

5. Stearner, S. P.: J. Exp. Zool. 115, 251 (1950)

6. Hartmann, A.: Arch. Entwickl. Organe 47, 131 (1920)

7. Rugh, R., Clugston, H.: Biol. Bull. 108, $318(1955)$

8. Frank, M. L.: Proc. Third Nat. Symp. Radioecol. 2, 1106 (1971)

9. Panke, T. W., Michaelson, S. M.: Am. J. Physiol. 220 (1), 174 (1971)

10. Simsa, J., Mraz, J.: Radiobiol. Radiother. 15 (4), 499 (1974)

11. Chlebovska, K., Chlebovsky, O., Praslicka, M.: Folia biol. (Praha) 24, (1978); Chlebovska, K., Praslicka, M., Chlebovsky, O.: Physiol. Bohemosl. 30, 557 (1981); Radiobiol. Radiother. 24 (1), 51 (1983); Chlebovska, K., Chlebovsky, O.: Physiol. Bohemosl. 35, 134 (1986); Radiobiol. Radiother. 28 (6), 795 (1987); 29 (5), 577 (1988)

12. Malhotra, N.: ibid. 25 (5), 699 (1984)

13. Esber, H. J., Zavorskas, P., Rosenkrantz, H.: J. Am. Collect. Toxicol. 3 (4), 317 (1984)
Naturwissenschaften 77, $182-185$ (1990) (C) Springer-Verlag 1990

\section{Spatial Interactions in the Fly Visual System Leading to Selectivity for Small-Field Motion}

\author{
M. Egelhaaf \\ Max-Planck-Institut für biologische Kybernetik, D-7400 Tübingen
}

Nerve cells which are selectively tuned to the motion of small objects are commonly found in the visual systems of invertebrates and vertebrates $[1-4]$. An example of such cells are the so-called

figure detection (FD) cells in the third visual ganglion of the fly [5]. Their likely role in visual orientation behavior was analyzed by correlating their response properties with the correspond- ing visually induced behavioral responses. In this way, the FD-cells have been concluded to play a role in discriminating moving objects from their background and in controlling orientation turns towards them [5-8]. Owing to their structural constancy and highly invariant functional properties, the FDcells can be identified individually in each animal, which greatly facilitates an analysis of the mechanisms underlying their specific spatial tuning. The present study provides combined pharmacological and electrophysiological 
evidence that at least one of the four types of FD-cells described so far [5], the FDl-cell, is selectively sensitive to small moving objects, because it is inhibited by the identified GABAergic

CH-cells, which respond best during large-field motion.

As all FD-cells, the FD1-cell resides in the lobula plate, the posterior part of the third visual ganglion of the fly's

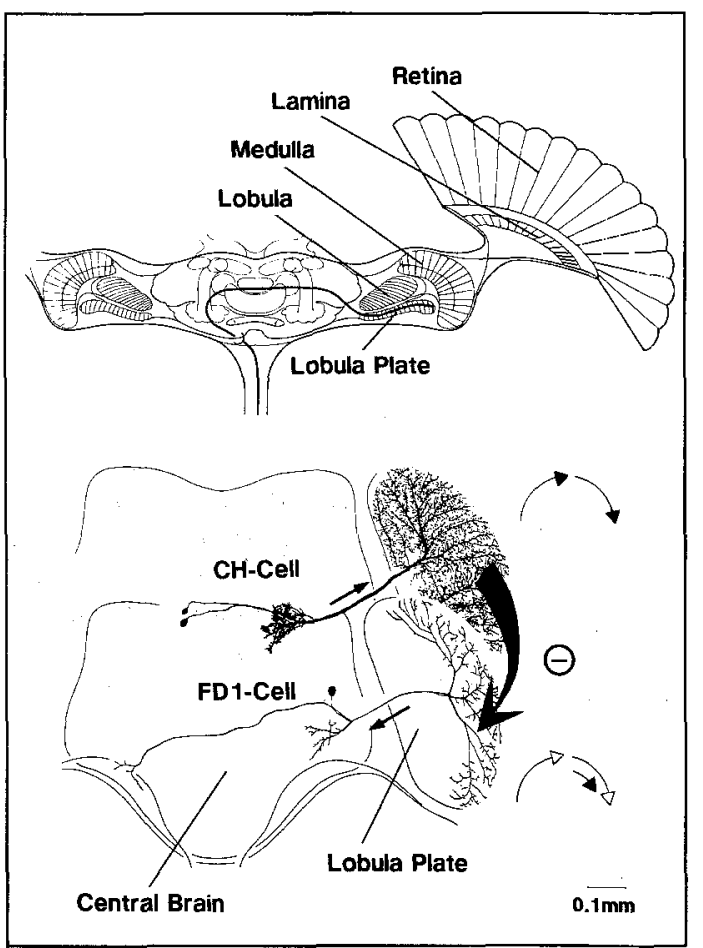

b

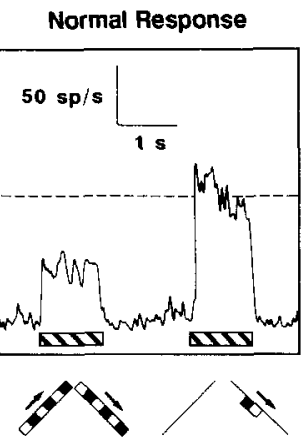

After Injection of Picrotoxinin

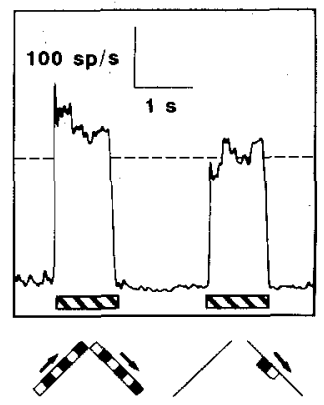

Fig. 1. a) Anatomy of the FD1-cell and its likely large-field inhibitor, the CH-cells. The cells are shown in front projections. Since their arborizations in the lobula plate lie closely behind each other, they were vertically offset as can be seen by the border lines of the dorsal part of the central brain and the lobula plate which are, therefore, shown twice. To allow better orientation a schematic horizontal cross-section through the nervous system is shown above the cells, with the retina, the three visual ganglia, and the central brain. The preferred directions of CH-cells and the FD1-cell are given schematically by the arrows on the right-hand side of the figure; black and open arrowheads indicate excitation and inhibition, respectively. Small-field motion from the front to the back in the visual field of the right eye activates the right FD1-cell. The FD1-cell is inhibited and the $\mathrm{CH}$-cells are excited by clockwise motion in the visual field of both eyes, respectively. The $\mathrm{CH}$-cells, thus, have the appropriate direction selectivities to act as the predicted large-field inhibitor of the FD1-cell (schematically indicated by the large arrow); the small arrows about parallel to the axons of the cells indicate the direction of signal flow in the cells (FD1-cell taken from [5]; CH-cells taken from [11]; the schematic diagram of the brain, modified from [13]). b) Spike frequency histograms of the response of the FD1-cell before (upper diagram) and about $120 \mathrm{~s}$ after injection of the GABA antagonist picrotoxinin (bottom diagram) as averaged during 10 consecutive presentations of the stimulation program. Stimuli were electronically generated on two CRT screens $\left(68^{\circ} \times 81^{\circ}\right.$; Tektronix 608) mounted symmetrically with respect to the long axis and the equatorial plane of the fly's head. The stimulus patterns were square-wave gratings moving with a constant velocity (spatial wavelength $8.5^{\circ}$; contrast 0.6 ; mean luminance $25 \mathrm{~cd} / \mathrm{m}^{2}$; temporal frequency $4 \mathrm{~Hz}$ ). They were produced by an image synthesizer (Picasso, Innisfree, Inc.) which was controlled by programs written in ASYST on an IBM-AT computer. The stimulus duration and direction of motion are indicated in the inset. The small-field stimulus had an angular horizontal extent of $17^{\circ}$, the large-field stimulus of $68^{\circ}$ in front of either eye. Before injection of picrotoxinin the FDl-cell responds in its characteristic way, i.e., with a larger response amplitude to small-field motion than to large-field motion. After injection of the GABA antagonist the mean spike frequency in response to motion increases considerably; most important, the response amplitudes are now somewhat larger during large-field than during small-field motion brain (Fig. 1a). All FD-cells are directionally selective for motion in a particular direction. The FD1-cell is excited by front-to-back motion in the frontolateral part of the visual field of one eye and inhibited by motion in the reverse direction [5]. This motion sensitivity is mediated by retinotopically arranged local movement detectors (for review, see e.g. [9]) with the appropriate preferred directions. Their output signals are assumed to be spatially pooled by the FD-cells' extended dentritic trees. The local movement detectors, however, cannot be the only input of the FD-cells. Since the FD-cells are activated most strongly during motion of relatively small objects (about $5^{\circ}-20^{\circ}$ angular size) in their excitatory receptive fields, but respond only weakly to more extended stimulus patterns, it was suggested that they are inhibited by large-field motion [5]. This inhibitory influence is induced by appropriately directed large-field motion in front of either eye. Both contralateral back-to-front motion as well as ipsilateral front-to-back motion reduces the response of the FD1-cell to simultaneous small-field motion in its excitatory receptive field. This means that coherent rotatory large-field motion about the vertical body axis of the animal exerts the strongest inhibitory influence on this cell [5].

This type of large-field inhibition can be explained in the simplest way by assuming that, in addition to its main input from local movement detectors, the FD1-cell is inhibited by an element which is sensitive to rotatory binocular large-field motion in the same direction as the FD1-cell's preferred direction. This large-field inhibitor may then interact with the FD1-cell either directly or, alternatively, with its local movement detector input elements $[6,10]$. It has been demonstrated by model simulations that such a mechanism is sufficient to explain the characteristic properties of FD-cells, if certain assumptions are made concerning the synaptic transmission properties of the FD-cells' local movement detector input elements [6].

A likely candidate in the fly's brain for the proposed large-field inhibitor of the FD1-cell is the pair of so-called $\mathrm{CH}$ cells. The $\mathrm{CH}$-cells are another type of motion-sensitive large-field elements which reside in the third visual ganglion 
(Fig. 1a) [11 - 15]. They are excited by rotatory binocular large-field motion just as was predicted for the large-field inhibitor of the FD1-cell. In contrast to the FD-cells, the $\mathrm{CH}$-cells do not receive their motion input directly by local movement detectors. Rather they are postsynaptic to other individually identified elements which are already sensitive to large-field motion [11 - 15]. The corresponding synaptic sites are on both the arborizations of the $\mathrm{CH}$-cells in the brain and the lobula plate, depending on the particular presynaptic element. The latter arborizations form also the output sites of the $\mathrm{CH}$-cells and, therefore, are both pre- and postsynaptic $[11,14]$. In conclusion, the $\mathrm{CH}$-cells convey information on rotatory binocular large-field motion to the lobula plate. There is twofold evidence that their action in the lobula plate is inhibitory. (1) It was reported that activation of the $\mathrm{CH}$-cells by depolarizing current inhibits the activity of another identified large-field element with the opposite preferred direction thereby enhancing its direction selectivity [13]. (2) Immunohistochemical labeling suggests that the $\mathrm{CH}$-cells are GABAergic and, thus, inhibitory elements [16]. It should be noted that, amongst the identified large elements of the lobula plate, which are sensitive to horizontal motion, the CH-cells were concluded to be the only GABAergic ones [16]. All these properties make the $\mathrm{CH}$-cells plausible candidates of the proposed large-field inhibitor of the FD1-cell.

Experimental evidence for this hypothesis could be obtained by injecting picrotoxinin (Sigma, $100 \mathrm{nl}$ of $1 \mathrm{mM}$ solution) into the fly's hemolymph just above the lobula plate while simultaneously monitoring the spike activity of the FD1-cell. Picrotoxinin is known to be a noncompetitive blocker of inhibitory chloride channels, especially, though not exclusively, of those activated by GABA [17]. Therefore, the inhibitory action of the $\mathrm{CH}$-cells was likely to be blocked by picrotoxinin. The FD1-cell was recorded extracellularly in the right optic lobe. (For a description of the preparation and the recording techniques, see [5].) The stimulus consisted of grating patterns generated electronically on two CRT screens $\left(68^{\circ} \times 81^{\circ}\right)$ which were placed symmetrically at an angle of $45^{\circ}$ in front of the fly (Calliphora erythrocephala). Coherent clockwise motion on both screens formed the large-field stimulus. Front-to-back motion in a $17^{\circ}$ wide partition of the right monitor screen in the FD1-cell's excitatory receptive field formed the small-field stimulus. In the experiments shown here, the fly was alternately confronted with large- and small-field motion with time intervals inbetween where the patterns were stationary.

The outcome of such an experiment is illustrated by the spike frequency histograms in Fig. 1b. Before application of picrotoxinin the FD1-cell responds in its characteristic way, i.e., with a higher spike frequency to small-field than to large-field motion (upper diagram in Fig. 1b). About 5-30 s after picrotoxinin was injected the responses change dramatically. The mean spike frequency during both large- and small-field motion increases. Most important, the response to large-field motion becomes slightly larger than the response to small-field motion (bottom diagram in Fig. 1b). Thus, the sensitivity of the FD1-cell to motion of small objects disappears. Between 10 and 30 min after application of picrotoxinin the small-field tuning of the FD1-cell fully recovers and the amplitudes of the responses to small- und large-field motion return to their pre-injection levels. This experiment, thus, corroborates the hypothesis that the $\mathrm{CH}$-cells may correspond to the large-field inhibitor of the FD1-cell and, thus, are likely to be responsible for its tuning to small-field motion.

This conclusion is not affected by the recent finding that picrotoxinin not only eliminates the small-field tuning of the FD1-cell, as described here, but also reduces direction selectivity of the local movement detectors $[18,19]$. Since the movement detectors are presynaptic to the FD-cells, it was not surprising that after injection of picrotoxinin a reduction in direction selectivity of the FD1cell was found in several experiments, in addition to an elimination of its small-field tuning. However, it appears that the small-field tuning of the FD1cell is more sensitive to the GABA antagonist than direction selectivity, since it can already be eliminated by relatively small amounts of picrotoxinin which usually do not significantly affect direction selectivity. This will be worked out in more detail in a forthcoming study.

How do the $\mathrm{CH}$-cells interact with the FD1-cell? They could inhibit the FD1cell either directly or indirectly via their presynaptic retinotopic movement-detecting input elements. Their extended telodendritic arborizations in the lobula plate (see Fig. 1a) suggest that the $\mathrm{CH}$ cells are not likely to synapse on the FD1-cell after convergence of its different dendritic branches. If the $\mathrm{CH}$ cells directly contact the FD1-cells, this interaction can be expected to be local and in parallel on the different branches of the FD1-cell's dendritic tree. The relevant anatomical data are not yet available to distinguish this possibility from the equally plausible alternative that the $\mathrm{CH}$-cells inhibit the presynaptic elements of the FD1-cells. The present study focused on the mechanism underlying the specific spatial tuning of only one of the FDcells, the FD1-cell. There are at least three other types of FD-cells which can be distinguished on the basis of their anatomy, receptive fields, and preferred directions [5]. Do all these FDcells acquire their sensitivity to smallfield motion, as the FD1-cell, via the $\mathrm{CH}$-cells? Owing to their preferred directions, the $\mathrm{CH}$-cells seem to be appropriate to play such a role for part of the FD-cells. However, the CH-cells are certainly not sufficient to act as the only large-field inhibitor of all FDcells. This is because part of the FDcells are inhibited by horizontal largefield motion oppositely directed to the CH-cells' preferred direction and others by large-field motion in either horizontal direction [5]. This makes at least another large-field inhibitor necessary with preferred directions opposite to that of the $\mathrm{CH}$-cells. In fact, there is an element in the lobula plate, discovered by $K$. Hausen, the so-called H5-cell, which may play this role [20]. From its direction selectivity and anatomy it seems to be destined, as the $\mathrm{CH}$-cells, to reconvey information on large-field motion to the lobula plate. So far, however, there is no experimental evidence that the $\mathbf{H 5}$-cell is an inhibitory element and plays a role, as is suggested for the CH-cells by the results presented here, in tuning part of the FD-cells to small-field motion.

How do visual interneurons in other systems acquire their sensitivity to 
small-field motion? It is generally agreed that these elements are inhibited, as the FD1-cell, in some way by cells with the same preferred direction but larger receptive fields $[1-4]$. To my knowledge, however, neither the elements responsible for this large-field inhibition nor the underlying synaptic mechanism could be characterized so far in any of these systems. The present findings on the mechanism of smallfield tuning of the FD1-cell, thus, demonstrates the significance of the fly for an understanding of fundamental principles of visual information processing in term of neuronal circuits.

I am grateful to A. Borst, T. Quenzer, W. Reichardt, and J. M. Zanker for critical discussions and for reading the manuscript. The figure is due to the skill of B. Pilz.
Received February 14, 1990

1. Collett, T. S.: Nature 232, 127 (1971)

2. Olberg, R. M.: J. Comp. Physiol. 141, 327 (1981)

3. Frost, B. J., Nakayama, K.: Science $220,744(1983)$

4. Allman, J., Miezin, F., McGuinness, E.: Perception 14, 105 (1985)

5. Egelhaaf, M.: Biol. Cybern. 52, 195 (1985)

6. Egelhaaf, M.: ibid. 52, 267 (1985)

7. Egelhaaf, M., Hausen, K., Reichhardt, W., Wehrhahn, C.: Trends Neurosci. 11, 351 (1988)

8. Reichardt, W., Egelhaaf, M., Guo, A.: Biol. Cybern. 61, 327 (1989)

9. Borst, A., Egelhaaf, M.: Trends Neurosci. 12, 297 (1989)

10. Egelhaaf, M.: Biol. Cybern. 52, 123 (1985)

11. Hausen, K.: Dissertation Univ. Tübingen 1976
12. Hausen, K.: Z. Naturforsch. 31 c, 629 (1976)

13. Hausen, K.: Verh. Dtsch. Zool. Ges. 74, $49(1981)$

14. Hausen, K., in: Photoreception and Vision in Invertebrates, p. 523 (ed. Ali, M A.). New York: Plenum 1984

15. Eckert, H., Dvorak, D. R.: J. Insect. Physiol. 29, 547 (1983)

16. Meyer, E. P., Matute, C., Streit, P., Nässel, D. R.: Histochemistry 84, 207 (1986)

17. Benson, J. A., in: Neurotox '88: Molecular basis of drug and pesticide action (ed. Lunt, G. G.). Amsterdam: Elsevier 1988

18. Schmid, A., Bülthoff, H.: Biol. Cybern 59, 71 (1988)

19. Egelhaaf, M., Borst, A., Pilz, B.: Brain Res. 509, 156 (1990)

20. Hausen, K., Egelhaaf, M., in: Facets of Vision (eds. Stavenga, D., Hardie, R.). Berlin-Heidelberg-New York: Springer 1989
Naturwissenschaften 77, $185-186(1990)$ (C) Springer-Verlag 1990

\section{The Seasonal Variation of the Angular Momentum of the Oceans}

\author{
P. Brosche and J. Wünsch \\ Sternwarte der Universität, D-5300 Bonn
}

\author{
A. Frische and J. Sündermann \\ Institut für Meereskunde der Universität, D-2000 Hamburg \\ E. Maier-Reimer and U. Mikolajewicz \\ Max-Planck-Institut für Meteorologie, D-2000 Hamburg
}

The main part of the seasonal variation of the (solid) Earth's angular velocity $\omega$ is caused by an exchange of angular momentum between the atmosphere and the solid Earth [1]. Observationally, the balance can be confirmed with an accuracy of about $10 \%$ of the variation [2]. The interchange with the oceans usually has been assumed to be small. In this article we present computations of its amount and phase.

Preliminary attempts to estimate the oceanic contribution from geostrophic currents based on insufficient data sets failed by one order of magnitude [3].
Here, we present results of a more advanced large-scale circulation model for the world ocean [4]. Laterally, this model resolves the circulation in grid steps of $3^{\circ} .5$. The vertical resolution involves 11 levels with 7 of them placed in the uppermost kilometer where the seasonal signal prevails. The model circulation was induced by seasonally varying boundary conditions at the sea surface. After 5000 years of model time the circulation had sufficiently adjusted to the forcing and reached a stationary state. We analyzed the model results for the final year of integration.
In this way, we obtained the angular momentum content $J_{\text {rel }}$ of the oceanic motions and the variations in the moment of inertia $\theta$ due to variations in sea level and density (strictly speaking, of their components around the Earth's axis of rotation). As expected, contributions of changes in the density stratification and changes in surface elevation almost compensate each other. The resulting net effect on seasonal variations in the moment of inertia amounts to about $10 \%$ of the density contribution. Each change $J_{\text {rel }}$ or $\Delta \theta \cdot \omega$ of the angular momentum of the oceans must be accompanied by a counteracting change of that of the solid Earth in order to retain the total. The two quantities and their effect $\Delta \omega$ on the angular velocity of the solid Earth are shown in Fig. 1a and b, together with an analytical approximation (Fourier series of up to the 2 nd degree). While the variation of $\theta$ requires at least a 2 nd degree representation, the currents reveal a simple sine wave. This difference probably results from a serious limitation in our applied forcing functions: for the Southern Ocean, in particular, there is a general lack of adequate data for wind stress and for seasurface values of temperature and 